\title{
IDENTIFYING THE RELATIONSHIP OF PARENTING STYLES AND PARENT'S PERFECTIONISM WITH NORMAL STUDENTS' AND GIFTED STUDENTS' PERFECTIONISM
}

\author{
Alireza Kakavand \\ Imam Khomeini International University, Iran \\ E-mail: alireza_kakavand@yahoo.com \\ Siavash Kalantari \\ Islamic Azad University, Iran \\ E-mail: siasis1@yahoo.com \\ Sima Noohi \\ Baqiyatallah University of Medical, Iran \\ E-mail: snouhi2005@yahoo.com \\ Hossein Taran \\ Islamic Azad University, Iran \\ E-mail: hosseintaran2713@gmail.com \\ Submission: $27 / 06 / 2016$ \\ Revision: 25/07/2016 \\ Accept: 27/07/2016
}

\section{ABSTRACT}

Psychologists stated that parents' functions and behaviors influence the formation of children's thoughts, behaviors and emotions This study aimed to identify the relationship of parenting styles and parents' perfectionism with normal students' perfectionism and gifted students' perfectionism. The study is a descriptive correlation study. The population consisted of all normal and gifted female high school students of Karaj. A sample of 200 students was selected using random sampling method. Data was collected using Hill's perfectionism questionnaire and BAUMRIND's parenting styles questionnaire. Researcher used simultaneous multivariate regression and independent sample t-test methods for data analysis. The results showed that there is a statistically significant difference between perfectionism of normal student's parents and perfectionism of gifted student's parents but there is no statistically significant difference between their parenting styles. 
There is a statistically significant difference between perfectionism of normal students and perfectionism of gifted students. Results also showed that adaptive and maladaptive perfectionism of students are not predictable based on the perfectionism and parenting styles of parents. what is happening in several major European Union (EU) countries in relation to Smart Cities development and subsequence ESCO growth, the important barriers they currently face to grow faster, and to find evidences of how collaboration between organizations could facilitate.

Keywords: Parenting Style, Perfectionism, Parents' Perfectionism, Normal Student, Gifted Student

\section{INTRODUCTION}

Academically gifted students exhibit high performance capability in intellectual areas, specific academic fields, or in both intellectual areas and specific academic fields. Myths that academically gifted students don't need help as they will do fine in their own and they are happy, popular and well-adjusted in school, have been proven wrong (TAM; PHILLIPSON, 2013).

Psychological researches stated that all children have potential abilities when they born, but because of various genetic and environmental reasons these abilities can be more in some people and less in others. According to studies the majority of population has a middle level of talent and a minority has more intelligence. Also a minority of population has little intelligence. Gifted students have various capabilities. They are distinguished from others by their exceptional ability --emotional, physical and cognitive-- (BETTS; NEIHART, 1988).

It seems that parents have a meaningful impact on their gifted children. Findings show that parents' attitudes and approaches have meaningful impact on gifted children's motivations and academic achievements. Because of some social, emotional, behavioral and educational perilous factors, education of gifted children is more challenging (MORAWSKA; SANDERS, 2009).

Psychologists stated that parents' functions and behaviors significantly influence the formation of children's thoughts, behaviors and emotions(CONGER et al,1992). 
Perfectionism is a personality construct and is characterized with features such as trying to be perfect and having some hard extreme measures for individual's functions (STOEBER ;OTTO, 2006; SLANEY; ASHBY; TRIPPI, 1995; FROST et al, 1990; HEWITT; FLETT, 1991).

Most of researchers believe that family and social environment have an important role in establishment and growing of children's perfectionism and also believe that perfectionism rooted in childhood experiences especially parent-child relationships. (BLATT, 1995; SOROTZKIN, 1998; VIETH; TRULL, 1999).

many research have been done to identify the roles of personality and parenting styles to the development of positive and negative perfectionism (BESHARAT et al., 2011).

Perfectionism responses produced independent clusters of unhealthy perfectionists, healthy perfectionists, and non-perfectionists. results revealed that both healthy- and non-perfectionists had significantly higher perceptions of maternal and paternal authoritativeness than unhealthy perfectionists Results indicate that exposure to heightened authoritative parenting may play a role in developing healthy perfectionist orientations (or decrease the likelihood of developing unhealthy perfectionist orientations) in youth sport (SAPIEIA et al., 2011).

Father's authoritarian style was significantly associated with dimensions of perfectionism in children, and father's authoritative style predicted changes in children's other oriented perfectionism. It can be concluded that authoritarian style of parenting effect on the development of children's perfectionistic characteristics (BESHARAT et al., 2011).

The results of a study found that positive perfectionism was significantly predicted by several factors including paternal authoritative style, openness to experiences, maternal authoritative style, and conscientiousness. On the other hand, negative perfectionism was significantly predicted by maternal authoritarian style, neuroticism, and paternal authoritarian style. As predicted, permissive parenting style showed no contribution in predicting positive and negative perfectionism. Implications, limitations, and recommendation of the study are addressed briefly in this research (BASIRON et al.,2014). 
DOI: 10.14807/ijmp.v8i1.501

\section{THEORIES OF PERFECTIONISM}

\subsection{Psychoanalytic Theory}

According to instinct theory, FREUD assumed that a strong stimulus such as neurotic need to be perfect should be instinctive. People who have strong need to be perfect increase expectations of themselves to the extent that will be destroyed under its weight.

\subsection{Gestalt Theory}

PIRLZ is one of the Gestalt theorists. He believes that all unfinished conditions -Incomplete Gestalt- form human. He says every one tends to integrity and perfection. Everything makes him away from this Gestalt-reaching perfection- is harmful

\subsubsection{BANDURA's Social Learning Theory}

BANDURA believes that human's behavior is a self-regulation behavior. Humans learn performance criteria via experience. If his performance is coordinated with his criteria, he will evaluate his performance positive. Rigid extremist criteria for self-evaluation leads to depression, discouragement and feelings of worthlessness.

\subsubsection{Humanism Theory}

The theorists of this theory such as ROGERS believe that human beings have an important brilliant motivation equipped from their birth. They have strong orientation to flourish and spreading all potential forces and abilities.

\subsubsection{Rational-Emotional Theory}

ALICE was the first cognitive- behavioral Theorist that explained perfectionism. From the view of this theorist, perfectionism is one of twelve irrational beliefs that lead to psychological distress. ALICE defined perfectionism as following: Acceptance of the belief that man/woman should be completely worthy and clever and should be leading in all matters.

\subsubsection{Two-Dimension Perfectionism (Positive Perfectionism and Negative Perfectionism)}

Perfectionism has a multi-dimensional structure and can be distinguished in two basic forms. 
Negative perfectionism-non adaptive-markers people who are wildly afraid of making mistakes, forecast their decisions, show delay in their work, and totally perfectionism is a kind of work blocker for them. In comparison, positive perfectionism -adaptive- markers people who their perfectionism attempts is enjoyable instead of paralyzing.

\subsubsection{Three-Dimension Perfectionism}

The concept of perfectionism posed by Hewitt and Flett, and empirical evidences supported it. Perfectionism includes three dimensions: self-centered perfectionism, other-centered perfectionism and society-centered perfectionism. The other-centered perfectionism is having perfectionist expect of others who are important like parents' perfectionist expect of children.

\subsubsection{Predisposing Factors of the Formation of Perfectionism}

Factors related to the development of perfectionism are defined as: factors related to parents, individual factors and biological factors.

\subsubsection{Factors Related to Parents}

\subsubsection{Parenting Style}

Parenting style consists of different elements combining to create an emotional atmosphere in which parents can declare their educative attitudes and activities to their children.

Parenting styles can be named as one of the features of family which is effective in children's growing up. As a causal factor, parenting style is the most important factor affecting perfectionism. Researchers believe that perfectionism is the result of the interaction of children with parents.

\subsubsection{BAUMRIND Parenting Style}

The most widespread typology of parenting in vest belongs to Baumrind (1966). BAUMRIND identified three parenting styles: authoritarian, magisterial and easy-taking (MANDARA, 2003).

The studies of Snowden and Christian (1999) show that parents having authoritarian parenting style -showing good parenting behaviors- support all aspects of growing such as suitable social, Cultural and educational opportunities. In a study, 
Dwairy (2004) stated that gifted students' parents who have authoritarian parenting style, in comparison with magisterial, positively affect their children's mental health. Magisterial parenting style is in contrast to the sense of autonomy of gifted children (MORAWSKA; SANDERS, 2009). So, understanding these styles and their impact on children's behavior will provide developments

\subsubsection{KROHNE \& PULSAC Parenting styles}

These parenting styles have two positive dimensions and three negative dimensions. Protection: A child's feeling about the amount of protection he/she receives in his/her activities. Praise: the amount of positive words a child receives. These are positive parenting styles. Blaming: a way parents show negative verbal reaction to their children. Restriction: not permitting or not encouraging child's spontaneous behaviors or decisions. Instability: perceived instability in parent's behaviors by the child. These are negative parenting styles.

\subsubsection{ADLER parenting styles}

ADLER is one of the theorists of parenting styles. STEIN added some matters to his point of view and presented a category as following:

- Promising style: parents confirm and respect child.

- Very easy going style: Parents give a lot of advantages to the child but they are careless to his/her main requirements

- Very obedient style: Parents surrender their child.

- Very serious style: parents monitor their child's behavior permanently.

- Perfectionist style: parents have high standards and will accept the child just if his/her performance is in accordance with standards.

- Very responsible style: because of different reasons such as economic conditions, death or illness of a parent, may assume heavy responsibilities to their children.

- Driving away style: parents don't accept the child and treat him/her like a nuisance.

- Careless style: parents have busy schedule and are not at home. 


\subsubsection{Personality Features of Parents}

The results of studies show that children who have high level of perfectionism attempts- individual criteria, self-centered perfectionism-have parents with high level of perfectionism attempts. (STOEBER; OTTO, 2006)

\subsubsection{Attachment Style}

Besides parenting style, attachment is the other factor relating to the formation of perfectionism.

\subsubsection{Unreasonable Assessment}

Irrational thinking means any thought causing Thrill, destructive and disintegrative behavior. And its result is impairment of joy and happiness.

\subsubsection{Biological Factors}

These factors are as following: Self-honor, self-assertive, achievement motivation and academic achievement.

Considering the abnormality of perfectionism, identifying the relationship between parenting styles and children's perfectionism will promote the perfectionism and personality theories. Teaching suitable parenting styles practically, it also helps education involved people to prevent this abnormal construction

Therefore, this study aims to identify the relationship between parenting styles and parents' perfectionism and normal students' perfectionism and gifted students' perfectionism. Accordingly, the research hypotheses are as follows:

\subsubsection{General hypotheses:}

- H1: the perfectionism of gifted students' parents and normal students' parents predicts perfectionism of gifted and normal students.

- H2: the parenting styles of gifted students' parents and normal students' parents predict perfectionism of their children.

\subsubsection{Dedicated hypotheses:}

- H1: the perfectionism of gifted students' parents is different from the perfectionism of normal students' parents. 
- H2: the parenting style of gifted students' parents is different from the parenting style of normal students' parents.

- H3: the perfectionism of gifted students is different from the perfectionism of normal students.

\section{METODOLOGY}

This research is a descriptive correlation study and in terms of use is foundation initiative. The population consisted of all normal and gifted female high school students of karaj. A sample of 200 students was selected using plant formula and multistage random sampling method. Data was collected using library resources, scientific magazines and supplies and standard questionnaires: Hill's perfectionism questionnaire and BAUMRIND's parenting style questionnaire.

HILLI's perfectionism questionnaire: this questionnaire has been investigated by Hill et al. (2007), which is a self-report objective one and has been prepared according to a cognitive-behavioral point of view. This questionnaire measures all components of both multi-dimensional tools. The Persian version having 58 phrases and 6 subscales (adaptive: targeted, order and organization, trying to be perfect and maladaptive: interpersonal sensitivity, perceived pressure from parents and high standards for others) has been validated and normalized by (HOOMAN; SAMAEE, 2010) --in Iranian model--. Answers were scored using Likert five-item spectrum.

The Cronbach's alpha coefficients and retest method were used to determine the reliability of questionnaire. Coefficient for the whole set was 0.926 and reliability of perfectionism questionnaire was conducted again on 50 people after 4 weeks. The correlation coefficient between two performances was 0.736 . This amount was significant at less than 0.001 . Validity of retest shows the stability of its basic structure. The structure was validated using factor analysis and principal components analysis with varimax rotation of questionnaire.

Baumrind's parenting style questionnaire: this questionnaire investigated by Baumrind (1972) and consists of 30 questions--10 questions for authoritarian style, 10 questions for magisterial style and 10 questions for easy-taking style-- measuring 3 parenting styles. Answers were scored using Likert five-item spectrum. Using retesting method, Bouri (1991) reported reliability of tool as following: easy-taking style 0.81 and 0.77 , magisterial style 0.86 and 0.85 and authoritarian style 0.78 and 
INDEPENDENT JOURNAL OF MANAGEMENT \& PRODUCTION (IJM\&P)

http://www.ijmp.jor.br

v. 8, n. 1, January - March 2017

ISSN: 2236-269X

DOI: 10.14807/ijmp.v8i1.501

0.88. He also mentioned the validity of tool. Surveying of 10 psychologist and psychiatrist, he reported a high validity. Using retest method within a week, he reported 0.76 for easy-taking style, 0.77 for magisterial style and 0.73 for authoritarian style.

Data obtained from questionnaires was analyzed using SPSS software to describe demographic information, assess normal distribution of sample, and determine the average of variables, and test the hypotheses using regression analysis methods. For this purpose, based on correlation coefficient and multiple regression equations, the relationships between variables were measured. Then, the findings were analyzed.

\subsection{Results of Testing First Hypothesis:}

The perfectionism of gifted students' parents and normal students' parents predicts maladaptive perfectionism of students. To test this hypothesis, assumptions of regression analysis --involving normality, linearity and multiple co-linearity--of parent's perfectionism dimensions investigated initially. The very small tolerance, less than 0.10 , and the big VIF, more than 10, is worrying and identifies multiple colinearity. According to results, there is no multiple co-linearity.

The relationship between parent's perfectionism as the predictor variable and gifted and normal student's maladaptive perfectionism as the criterion variable was analyzed simultaneously. According to $\mathrm{P}=0.537$ and $\mathrm{F}=0.856$ in gifted students, it can be said that linear combination of predictor variables can't explain criterion variable which is gifted student's maladaptive perfectionism. Also considering $\mathrm{P}=0.455$ and $\mathrm{F}=0.978$ in normal students, we can conclude that linear combination of predictor variables can't explain criterion variable which is normal student's maladaptive perfectionism. So the variance of maladaptive perfectionism in both gifted and normal students cannot be explained by their parents' perfectionism dimensions. Considering Beta indexes, it can be said that none of parents' perfectionism dimensions predicts normal and gifted students' maladaptive perfectionism.

The perfectionism of gifted students' parents and normal students' parents predicts adaptive perfectionism of students. To test this hypothesis, assumptions of regression analysis --involving normality, linearity and multiple co - linearity-- of 
INDEPENDENT JOURNAL OF MANAGEMENT \& PRODUCTION (IJM\&P)

http://www.ijmp.jor.br

v. 8, n. 1, January - March 2017

ISSN: 2236-269X

DOI: 10.14807/ijmp.v8i1.501

parent's perfectionism dimensions investigated initially. The very small tolerance, less than 0.10 , and the big VIF, more than 10 , is worrying and identifies multiple colinearity. According to results, there is no multiple co-linearity.

The relationship between parent's perfectionism as the predictor variable, and gifted and normal students' adaptive perfectionism as the criterion variable was analyzed simultaneously. According to $P=0.90$ and $F=0.358$ in gifted students, it can be said that linear combination of predictor variables can't explain criterion variable, gifted student's adaptive perfectionism. Also considering $P=0.144$ and $F=1.73$ in normal students, we can conclude that linear combination of predictor variables can't explain criterion variable, normal student's adaptive perfectionism. So the variance of adaptive perfectionism in both gifted and normal students cannot be explained by their parents' perfectionism dimensions. Considering Beta indexes, it can be said that none of parents' perfectionism dimensions predicts normal and gifted students' adaptive perfectionism

\subsection{The Results of Testing Second Hypothesis:}

The parenting styles of gifted students' parents and normal students' parents predict adaptive perfectionism of students. To test this hypothesis, assumptions of regression analysis --involving normality, linearity and multiple co - linearity-- of parent's parenting styles investigated initially. The very small tolerance, less than 0.10 , and the big VIF, more than 10 , is worrying and identifies multiple co-linearity. According to results, there is no multiple co-linearity.

The relationship between parenting style dimensions as the predictor variable and gifted and normal student's adaptive perfectionism as the criterion variable was analyzed simultaneously. According to $\mathrm{P}=0.546$ and $\mathrm{F}=0.722$ in gifted students, it can be said that linear combination of predictor variables can't explain criterion variable, gifted student's adaptive perfectionism. Also considering $P=0.990$ and $\mathrm{F}=0.037$ in normal students, we can conclude that linear combination of predictor variables can't explain criterion variable which is normal student's adaptive perfectionism. So the variance of adaptive perfectionism dimensions in both gifted and normal students cannot be explained by their parents' parenting style dimensions. Considering Beta indexes, it can be said that none of parents' parenting style dimensions predicts normal and gifted students' adaptive perfectionism. 
The parenting styles of gifted students' parents and normal students' parents predict maladaptive perfectionism of students. To test this hypothesis, assumptions of regression analysis --involving normality, linearity and multiple co- linearity -- of parent's parenting styles investigated initially. The very small tolerance, less than 0.10 , and the big VIF, more than 10 , is worrying and identifies multiple co-linearity. According to results, there is no multiple co-linearity.

The relationship between parents' parenting style dimensions as the predictor variable and gifted and normal student's maladaptive perfectionism as the criterion variable was analyzed simultaneously. According to $\mathrm{P}=0.452$ and $\mathrm{F}=0.897$ in gifted students, it can be said that linear combination of predictor variables can't explain criterion variable which is gifted student's maladaptive perfectionism. Also considering $\mathrm{P}=0.976$ and $\mathrm{F}=0.068$ in normal students, we can conclude that linear combination of predictor variables don't explain criterion variable which is normal student's maladaptive perfectionism. So, the variance of maladaptive perfectionism dimensions in both gifted and normal students cannot be explained by their parents' parenting style dimensions. Considering Beta indexes, it can be said that none of parents' parenting style dimensions predicts normal and gifted students' maladaptive perfectionism.

\section{DISCUSSION AND CONCLUSION}

- The perfectionism of gifted students' parents is different from the perfectionism of normal students' parents.

- The perfectionism of gifted students is different from the perfectionism of normal students.

- The parenting style of gifted students' parents is different from the parenting style of normal students' parents.

Due to the lack of the assumptions of multivariate analysis of variance, the researcher used independent sample t-test to test above hypothesizes. Findings show that the scores of gifted students' parents in perfectionism subscales like adaptive perfectionism, maladaptive perfectionism, order and organization, trying to be perfect and interpersonal sensitivity are different from the scores of normal student's parents. 
And the average of scores of normal students' parents is higher than the scores of gifted students' parents. There was no statistically difference between the parenting styles of gifted students' parents and the parenting style of normal students' parents.

Findings show that the scores of gifted students in adaptive perfectionism, maladaptive perfectionism, interpersonal sensitivity, trying to be perfect, order and organization, perceived pressure and high standards are different from the scores of normal students. And the average of scores of normal students is higher than the average of scores of gifted students. Since there is no research reviewing these assumptions, researcher cannot judge the compatibility of these findings with others.

Morawska and Sanders (2009) were the only researchers who studied about parenting styles. They stated that gifted students' parents need to have some special parenting styles and strategies to manage emotional and behavioral vulnerabilities of their gifted children. About the inconformity of these finding with previous one, it can be said that lack of variation of parenting styles of gifted students' parents and parenting styles of normal students' parents is due to their same parental awareness about parenting styles.

Gifted students' parents are not necessarily more awareness about suitable and effective educational practices. This is the first reason for non-different parenting styles of these two groups. The other reason is the concept of cleverness. It seems that in Iran the separation criterion are more related to educational information to intelligence. So, it is a very important issue to separate gifted students from normal students based on knowing the level of their cleverness.

Findings confirmed that parent's perfectionism impacts on children's perfectionism. Perfectionist parents refuse their children's behaviors and put pressure on them to be perfect. Parent's criticism and their expectations are as the main components of perfectionism.

- The perfectionism of gifted students' parents and normal students' parents predicts student's perfectionism.

Using the standard multivariate regression analysis to investigate the above hypothesis, findings show that the linear combination of predictor variables, parent's perfectionism, does not predict the criterion variable, adaptive and maladaptive 
INDEPENDENT JOURNAL OF MANAGEMENT \& PRODUCTION (IJM\&P)

http://www.ijmp.jor.br

v. 8, n. 1, January - March 2017

ISSN: 2236-269X

DOI: 10.14807/ijmp.v8i1.501

perfectionism of students. Also none of predictor variables alone predicts the criterion variable. This result is inconsistent with the results of Eliot and McGregor (2001). They said that incompatible perfectionism of children can be predicted by abnormal perfectionism of parents; in return compatible perfectionism of children can be predicted by normal perfectionism of parents (ABBASPOUR et al, 2006).

In explaining the research findings, it can be stated that parent's perfectionism is one of the predictors of students' perfectionism. Several factors such as biological agents are involved in children's perfectionism. So, it cannot be predicted just by parent's perfectionism. The genetic vulnerability of perfectionism is based on biological vulnerability to negative affection. So, this genetic predisposition to negative affection may be the basis of perfectionism (MEHRABIZADE, 2001).

- The parenting style of gifted students' parents is different from the parenting style of normal students' parents.

Standard multivariate regression analysis was used to investigate the above hypothesis. Hypothesis test results show that the linear combination of predictor variables --parenting styles-- predicts the criterion variable which is adaptive and maladaptive perfectionism of gifted and normal students.

This argument is inconsistent with research results of Frost (1999) and Hewitt et al (1992). Parenting style is the main causal factor impacting perfectionism. Most researchers believe that perfectionism is a result of the interaction of children with their parents. Perfectionist children mostly grow up in families who criticize performances less than perfect. So in such expected family's children learn to critically evaluate their own performances. Research findings show that there is a direct relationship between rough majestic parenting style and negative aspects of perfectionism.

Unlike majestic parents, authoritative parents empower the relations with their children. Seeking the views of their children, they allow them to participate in the legislations. This parenting style has a direct relationship with positive aspects of perfectionism. Along with parenting styles, affection is another factor related to perfectionism. Rice and Mirzade (2000) in their study found that secure affection to parents strongly predicts students' adaptive perfectionism. 
In explaining the research findings, it can be said that although parent's parenting style is one of the predictors of students' perfectionism, but it is not the only factor, and several factors such as biological agents are involved in children's perfectionism.

\section{CONCLUSION}

In this study the relationship between parenting styles and parents' perfectionism and normal students' perfectionism and gifted students' perfectionism was investigated. None of the dimensions of parents' perfectionism alone predict adaptive and maladaptive perfectionism of gifted and normal students. According to results adaptive and maladaptive perfectionism of gifted and normal students cannot be explained by parenting style.

Results confirm that the gifted students' parent's perfectionism subscales like adaptive perfectionism, maladaptive perfectionism, order and organization, trying to be perfect and interpersonal sensitivity are different from the normal student's parents. Also gifted student's adaptive perfectionism, maladaptive perfectionism, interpersonal sensitivity, trying to be perfect, order and organization, perceived pressure and high standards are different from normal students.

Results indicate that none of the dimensions of parents' parenting styles alone predict adaptive and maladaptive perfectionism of gifted and normal students.

\section{REFRENCES}

ABBASPOUR, P; FARAHANI, M. T; SHARARAY, M. (2006). The relationship between perfectionism and self-confidence and mental health. Dissertation (Phd in psychology). Tehran: Teacher Training university of Tehran. Tehran

BAUMRIND, D. (1966). Effects of authoritative parental control on child behavior. Child Development, v. 37, p. 887-907.

BELSKY, J. (2005). Family influences on psychological development. Psychiatry, v. 41, p. 41-4141.

BESHARAT, M. A.; AZIZI, K.; POURSHARIFI, H. (2011). The relationship between parenting styles and children's perfectionism in a sample of Iranian families.

Procedia Social and Behavioral Sciences, v. 15, p. 1276-1279.

http://dx.doi.org/10.1016/j.sbspro.2011.03.276

BETTS. G. T; NEWHART, M. (1988). Profiles of the gifted and talented children. Gifted child Quarterly, v. 32, n. 2, p. 248-253.

BLATT, S. J. (1995). The destructiveness of perfectionism: Implications for the treatment of depression. American psychologists, v. 50, p. 1003-1020. 
CONGER, R. D.; CONGER, K. J.; ELDER, J. R.; LORENZ, F. O.; SIMONS, R. L.; WHITBECK, L. B. (1992). A family process model of economic hardship and adjustment of early adolescent boys. Child Develoment, v. 63, n. 3, p. 526-541.

DWAIRY, M. (2004). Parenting styles and mental health of Arab gifted adolescents. Gifted Child Quarterly, v. 48, n. 4, p. 275-286.

DWAIRY, M.; MENSHAR, K. E. (2006). Parenting style. Individuation, and mental health of Egyptian adolescents. Journal of Adolescence, v. 29, p.103-117.

ELLIOT, A. G. ; MCGREGOR, H. A. (2001). A2.2achivementgoal framework. journal of personality and social psychology, v. 80, n. 3, p. 501.

FROST, R. O.; MARTEN, P.; LAHART, C.; ROSENBATE R. (1990). The dimensions of perfectionism. Cognitive therapy and research, v. 14, p. 449-468.

HEWITT, P.; FLETT, G. L. (1991). perfectionism in the self-social contexts: conceptualization, assessment, and association with psychopathology. Journal of personality and social psychology, v. 60, p. 456-470.

HILL, V. Z.; TERRY, C. (2007). Perfectionism and explicit self - esteem: the moderating role of implicit self - esteem. Self and identity, v. 6, p.137-153.

MANDARA, J. (2003). The Typological approach in child and family psychology: A review of theory. Methods and research. Clinical child and family psychology review, v. 6, p.129-146.

MEHRABIZADE HONARMAN, M. (2001). The relationship between parenting styles and mental health and coordination of self-assumptions' components. Psychology and training sciences, p. 285-297.

MORAWSKA, A.; SANDERS, M. R. (2009). Parenting gifted and talented children: conceptual and empirical foundations. Gifted Child Quarterly, v. 53, n. 3, p. 163173.

RICE, K. G.; MIRZADE, S. A. (2000). Perfectionism, attachment \& adjustment. Journal of counseling psychology, v. 47, n. 2, p. 238-250.

SAPIEJA, K. M.; DUNN, JOHN G. H.; HOLT, N. L. (2011). Perfectionism and Perceptions of Parenting Styles in Male Youth Soccer. Journal of Sport \& Exercise Psychology, v. 33, p. 20-39

SLANEY, R. B.; ASHBY, J. S.; TRIPPI. J. (1995). Perfectionism: Its measurement and career relevance. Journal of career assessment, v. 3, p. 279-297.

SNOWDEN, P. L.; CHRISTIAN, L. G. (1999). Parenting the young gifted child: Supportive behaviours. Roeper Review, v. 21, n. 3, p. 215-221.

SOROTZKIN, B. (1998). Understanding and treating perfectionism in religious adolescents. Psychotherapy, v. 35, p. 87-95.

STOEBER, J.; OTTO, K. (2006). Positive conceptions of perfectionism: Approaches, evidence, challenges personality and psychology review n. 10, p. 293-319.

TAM, C. S.; PHILLIPSON, S. N. (2013). Parenting and the social-emotional development of gifted students in Hong Kong: A review of the literature based on the actiotope model of giftedness. Australasian Journal of Gifted Education, v. 22, n. 1, p. 51-61. 
VIETH, A. Z.; TRULL, T. J. (1999). Family patterns of perfectionism: An examination of college students and their parents. Journal of personality assessment, v.12 , p. 49-67.

ZAINON BASIRION; ROSADAH ABD MAJID; ZALIZAN MOHD JELAS (2014). Big Five Personality Factors, Perceived Parenting Styles, and Perfectionism among Academically Gifted Students. Asian Social Science, v. 10, n. 4. 